\title{
Pengaruh Jenis Target Sasaran Bidikan pada Pengukuran Jarak Hasil Pengukuran Electronic Total Station Reflector-less
}

\author{
RINALDY, A.S. SETIADI, M.A. BASYID \\ Jurusan Teknik Geodesi - Fakultas Taknik Sipil dan Perencanaan, \\ Institut Teknologi Nasional (Itenas) Bandung \\ Email: rinaldy583@gmail.com
}

\begin{abstract}
ABSTRAK
Electronic Total Station (ETS) merupakan gabungan dari alat ukur sudut dan jarak digital serta unit pemrosesan dan unit perekaman data. ETS Reflector-less merupakan sistem pada ETS untuk Electronic Distance Meter (EDM) atau alat pengukur jarak tanpa reflector. Spesifikasi ketelitian jarak reflector-less pada alat ETS Hi-Target ZTS 320R adalah sebesar $(3 \mathrm{~mm}+2 p p m \times D) \mathrm{mm}$, dimana $D$ adalah panjang jarak ukuran dalam satuan kilometer. Pada penelitian ini dilakukan kajian pengaruh jenis target terhadap kualitas hasil pengukuran ETS Reflector-less. Perbandingan jarak antara pita ukur baja dan ETS reflector-less dilakukan sebanyak 30 kali dengan jarak $20 \mathrm{~m}, 30 \mathrm{~m}$, dan $50 \mathrm{~m}$ untuk masing-masing jenis target tembok bangunan, besi, kayu dan tanah. Hasil yang diperoleh ketelitian jarak reflector-less untuk jenis target tembok bangunan sebesar $\pm 0.002 \mathrm{~m}$, jenis target besi sebesar \pm 0.002 $m$, jenis target kayu sebesar $\pm 0.001 \mathrm{~m}$, dan jenis target tanah sebesar $\pm 0.002 \mathrm{~m}$.
\end{abstract}

Kata kunci : ketelitian, jarak, reflector-less, ETS Hi-Target ZTS 320R

\begin{abstract}
Electronic Total Station (ETS) is a combination of reflector-less digital angle and distance measuring devices as well as processing units and data recording units. Reflector-less is a system on ETS for Electronic Distance Meter (EDM) or a distance meter without reflector. The specification of the accuracy of the reflector-less distance on the ETS Hi-Target ZTS $320 R$ is equal to $(3 \mathrm{~mm}+2 p p m \times D) \mathrm{mm}$, where $D$ is the length of the distance distance in kilometers. This research aims to study the influence of the type of target on the accuracy of measurement results derived from ETS Reflector-less. The comparison of distance measurements between steel measuring tape and ETS reflector-less were performed 30 times with spacing of $20 \mathrm{~m}, 30 \mathrm{~m}$, and $50 \mathrm{~m}$ for each target type, i.e building wall, iron, wood and soil. The accuracy of the ETS reflector-less distance for the building wall target type is $\pm 0.002 \mathrm{~m}$, the target type of iron is $\pm 0.002 \mathrm{~m}$, the target type of wood is \pm 0.001 $m$, and the target type of land is $\pm 0.002 \mathrm{~m}$.
\end{abstract}

Keywords: accuracy, distance, reflector-less, ETS Hi-Target ZTS 320R 


\section{PENDAhUlUAN}

Geodesi secara umum merupakan disiplin ilmu kebumian yang mempelajari tentang pengukuran dan representasi permukaan bumi dan benda-benda langit lainya, dalam ruang tiga dimensi yang berubah terhadap waktu (Anonim, 1979). Sudut pandang lain geodesi diartikan sebagai cabang ilmu matematika terapan yang melakukan pengukuran dan pengamatan untuk menentukan suatu posisi titik di permukaan bumi, ukuran, bentuk, dan luas sebagian besar permukaan bumi yang kemudian disajikan hasilnya menggunakan media tertentu.

Seiring dengan perkembangan teknologi di bidang komputer, informasi, dan komunikasi yang begitu cepat, disiplin ilmu geodesi mengalami perubahan dalam hal ruang lingkup keilmuan dan bidang keahlian teknik, yang dikenal dengan nama geomatika (Anonim, 1979). Perkembangan teknologi yang semakin hari terus berkembang dan semakin canggih yang terjadi pada semua bidang kehidupan tak terkecuali pada bidang Geodesi. Perkembangan bidang Geodesi banyak hal baru maupun pengembangan dari produk yang ditawarkan. Teknologi yang hadir saat ini diantaranya teknologi ETS (Electronic Total Station) yang dapat digunakan untuk mendapatkan koordinat suatu titik dengan waktu yang singkat, sehingga memudahkan proses penentuan posisi yang mempunyai banyak titik.

Saat ini telah ada perkembangan teknologi terkait dengan alat ETS, yaitu reflector-less atau sistem laser pada ETS yang tidak memerlukan prisma reflector sebagai target. Salah satu penggunaan reflector-less adalah untuk memetakan suatu lahan atau daerah dengan waktu yang relatif singkat tanpa terhambat oleh pergerakan prisma reflector dalam proses pengukuran banyak titik. Sejak kemunculan alat ETS hingga saat ini, teknologi ini digunakan untuk penentuan posisi atau pemetaan suatu lahan yang memerlukan akurasi tinggi seperti pembuatan kerangka horizontal dan vertikal, stake-out (penentuan posisi dilapangan sesuai dengan posisi pada peta perencanaan), detail topografi, pengukuran sudut dan jarak, dan lain-lain.

Selain beberapa kelebihan pada Electronic Total Station Reflector-less yang telah disebutkan, ada pula beberapa kekurangannya. Kekurangan pada sistem reflector-less terdapat pada kualitas data yang dihasilkan tidak hanya tergantung pada reflector-less itu sendiri, tetapi dipengaruhi juga oleh karakteristik objek yang berbeda. Salah satu pengaruh objek tersebut yaitu jenis target berbeda (misalkan jenis material kayu, besi, batu, tanah, dan lain-lain) yang dapat mempengaruhi kualitas pada hasil pemindaian posisi dengan sistem reflectorless. Selain jenis target, jarak objek terhadap ETS juga akan mempengaruhi kualitas hasil pemindaian, karena jarak yang terlalu dekat ataupun jarak yang terlalu jauh akan mempengaruhi kualitas hasil pemindaian pada alat ETS (Anonim, 2017).

Pada penelitian ini, dilakukan kajian pengaruh jenis target terhadap kualitas hasil pengukuran ETS Reflector-less. Pemetaan menggunakan ETS reflector-less pada suatu daerah tentunya terdiri dari berbagai jenis target yang berbeda yang akan mempengaruhi hasil ketelitian pengukuran atau adanya perbedaan ketelitian tergantung jenis targetnya. Pada penelitian ini diharapkan dapat diketahui pengaruh dari beberapa jenis target terhadap ketelitian hasil pengukuran ETS Reflector-less, agar penggunaan ETS Reflector-less dapat digunakan semaksimal mungkin dalam mendapatkan hasil ketelitian yang lebih baik. 


\section{METODOLOGI PENELITIAN}

Penelitian ini dilakukan untuk membandingkan ketelitian jarak antara hasil ukuran menggunakan pita ukur baja dan hasil ukuran ETS reflector-less yaitu jenis ETS Hi-Target ZTS 320 R dimana setiap pengukuran jarak dilakukan sebanyak 30 kali. Selain itu dikaji ketelitian jarak hasil ukuran ETS reflector-less terhadap beberapa jenis target, yaitu: tembok, besi, kayu, dan tanah. Teknis pengukuran jarak dilakukan seperti pada gambar 1 .

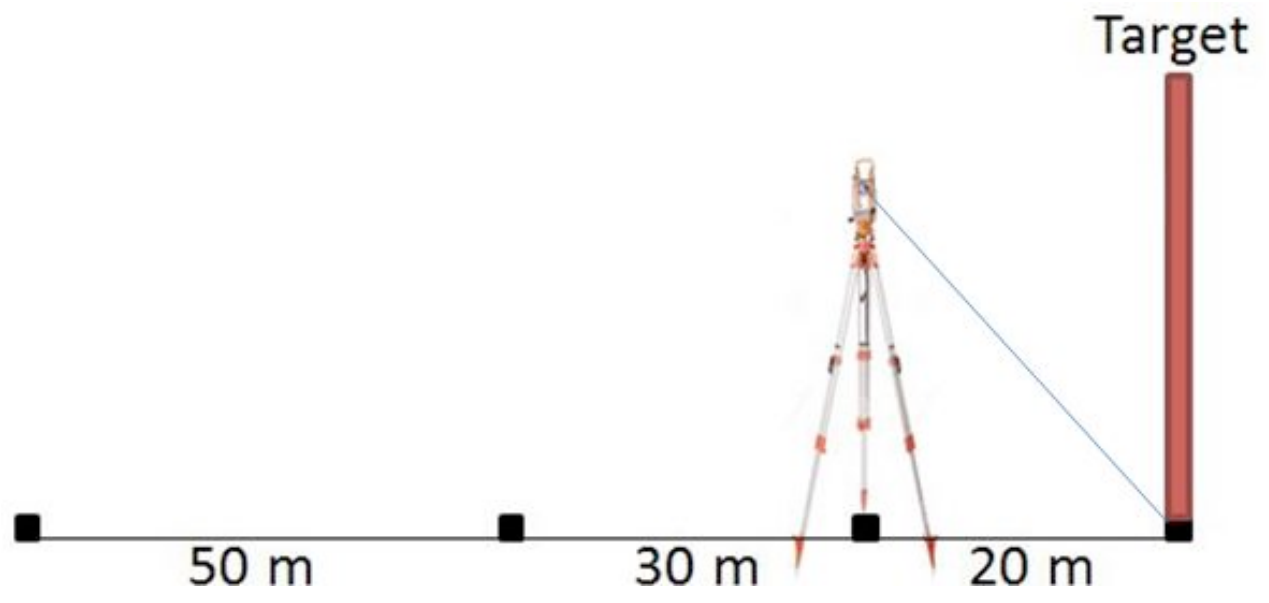

Gambar 1. Sketsa pengukuran jarak ETS reflector-less target langsung

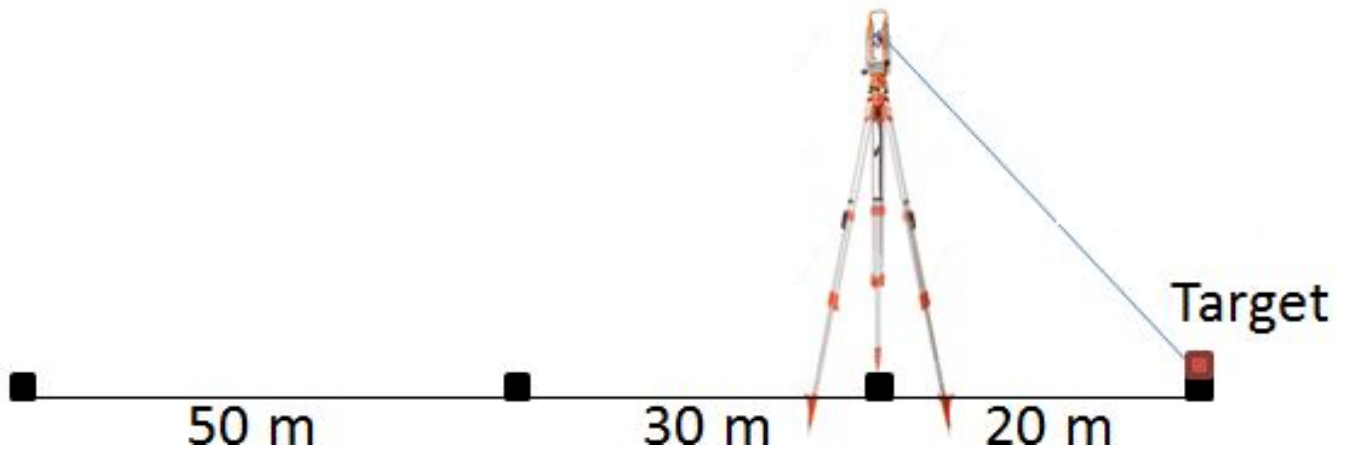

Gambar 2. Sketsa pengukuran jarak ETS reflector-less target sampel

Proses pengolahan data dilakukan dengan cara menghitung besar kesalahan pada pengukuran jarak elektronik menggunakan persamaan berikut (Ghilani, 2010; Wolf, 1997):

$$
\begin{aligned}
& \sigma_{d}=\sqrt{\sigma_{i}^{2}+\sigma_{r}^{2}+a^{2}+(D \times b p p m)^{2}} \\
& \sigma_{i}=0,5\left(\frac{\mathrm{mm}}{\mathrm{m}}\right) \times \text { tinggialat }(\mathrm{m})
\end{aligned}
$$

Dimana $\sigma_{d}$ adalah ketelitian pengukuran jarak menggunakan EDM, $\sigma_{i}$ adalah pengaruh kesalahan sentring alat terhadap hasil ukuran jarak, $\sigma_{r}$ adalah pengaruh kesalahan sentring target terhadap hasil ukuran jarak, $a$ dan $b$ adalah konstanta ketelitian alat $= \pm(a+b$ ppm), dan D adalah jarak ukuran dalam satuan kilometer $(\mathrm{km})$. Simpangan baku diperlukan untuk analisis ketelitian hasil ukuran, yang dihitung menggunakan persamaan berikut (Boediono, 2011): 


$$
\sigma=\sqrt{\frac{\sum(x-\bar{X})^{2}}{n-1}}
$$

dimana $\mathrm{x}$ merupakan data, $\overline{\mathrm{X}}$ merupakan rata-rata data, dan $\mathrm{n}$ merupakan jumlah semua data.

Proses pelaksanaan penelitian ini terdiri atas tahapan studi literatur, pemahaman alat, pengukuran jarak, pengolahan data, dan analisis ketelitian jarak. Adapun diagram alir metodologi penelitian dijelaskan pada Gambar 3.

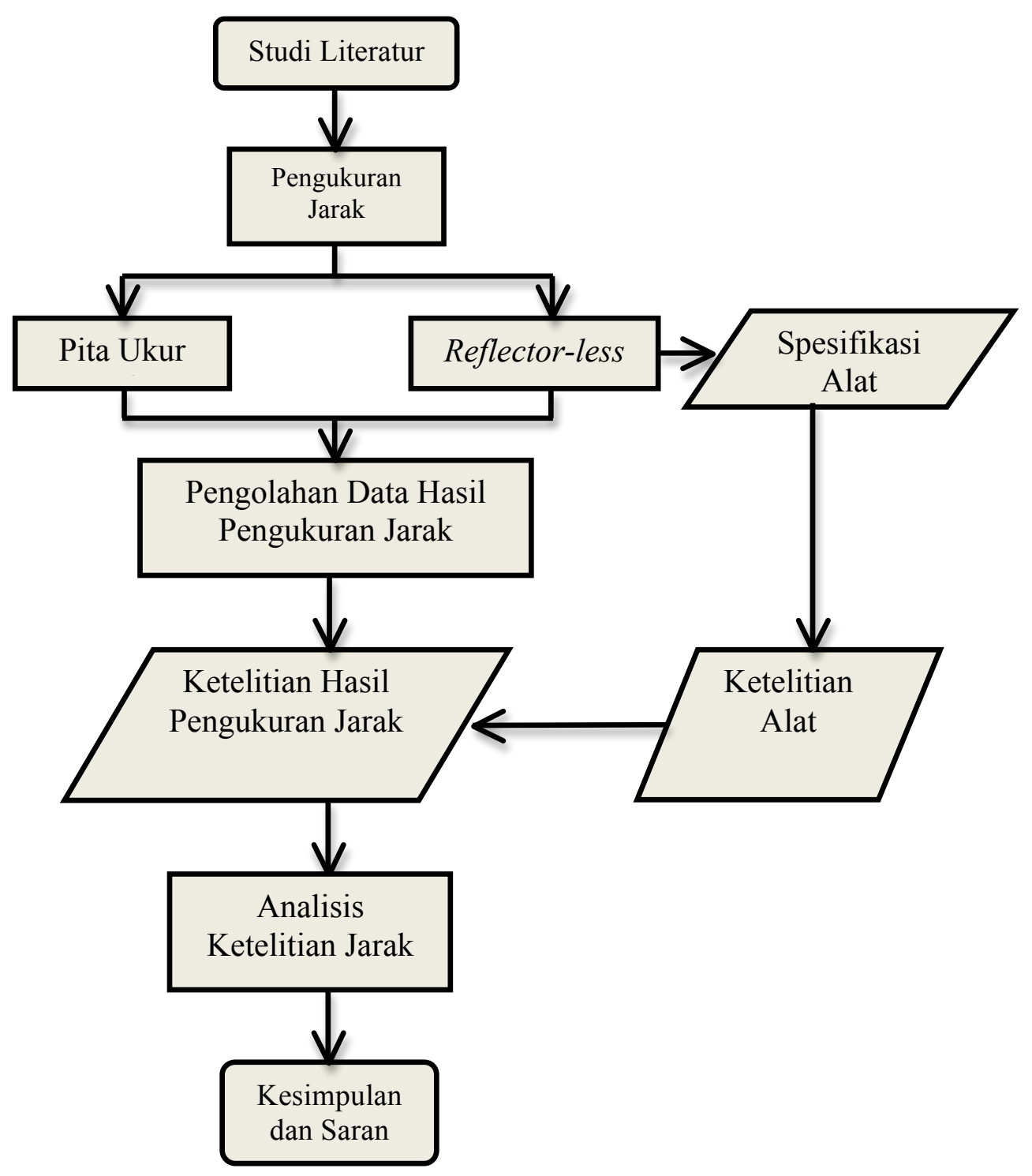

Gambar 3. Diagram alir penelitian

Analisis ketelitian jarak ETS reflector-less untuk setiap jenis target dilakukan dengan cara membandingkan hasil ketelitian jarak dengan spesifikasi ketelitian jarak reflector-less $(3 \mathrm{~mm} \pm 2 \mathrm{ppm})$. Untuk besaran pengaruh jarak dari jenis target didapat dari selisih jarak pita ukur baja dengan jarak ETS reflector-less yang sudah terbebas dari kesalahan pengukuran jarak. 


\section{HASIL DAN ANALISIS}

Setelah dilakukan pengukuran jarak ETS reflector-less sebanyak 30 kali pada semua jenis target, kemudian dilakukan pengolahan data untuk mendapat ketelitian jarak ETS reflectorless menggunakan persamaan (1) dan menghitung selisih jarak pita ukur baja dengan jarak reflector-less yang sudah terbebas dari kesalahan pengukuran jarak untuk mendapatkan besaran pengaruh jenis target terhadap ukuran jarak. Berikut hasil yang sudah didapat (Tabel 1).

Tabel 1. Rata-rata jarak hasil pengukuran ETS reflector-less

\begin{tabular}{|c|c|c|c|c|}
\hline \multirow{2}{*}{ Jenis Target } & \multicolumn{3}{|c|}{ Rata-rata Jarak } & \multirow{2}{*}{$\sigma_{\mathrm{D}}(\mathrm{m})$} \\
\cline { 2 - 4 } & $20 \mathrm{~m}$ & $30 \mathrm{~m}$ & $50 \mathrm{~m}$ & \\
\hline Tembok Bangunan & 20.000 & 30.001 & 50.000 & 0.003 \\
\hline Besi & 20.001 & 30.002 & 50.002 & 0.003 \\
\hline Kayu & 20.000 & 30.002 & 49.999 & 0.003 \\
\hline Tanah & 20.001 & 30.001 & 50.000 & 0.003 \\
\hline
\end{tabular}

Berdasarkan Tabel 1 didapatkan kesalahan pengukuran jarak ETS reflector-less sebesar \pm $0.003 \mathrm{~m}$ untuk semua jenis target.

Tabel 2. Selisih jarak pita ukur baja dan ETS reflector-less

\begin{tabular}{|c|c|c|c|c|}
\hline \multirow{2}{*}{ Jenis Target } & \multicolumn{3}{|c|}{$\sigma_{\text {selisih }}(\mathrm{mm})$} & \multirow{2}{*}{ Rata-rata } \\
\cline { 2 - 4 } & Jarak $20 \mathrm{~m}$ & Jarak $30 \mathrm{~m}$ & Jarak $50 \mathrm{~m}$ & \\
\hline Tembok Bangunan & 2.524 & 0.469 & 1.125 & 1.373 \\
\hline Besi & 0.611 & 0.429 & 0.690 & 0.576 \\
\hline Kayu & 0.678 & 0.181 & 0.809 & 0.556 \\
\hline Tanah & 1.736 & 3.079 & 1.917 & 2.244 \\
\hline
\end{tabular}

Berdasarkan Tabel 2 didapat rata-rata selisih jarak antara pita ukur baja dan ETS reflectorless pada jenis target bangunan sebesar $\pm 1.373 \mathrm{~mm}$, target besi sebesar $\pm 0.576 \mathrm{~mm}$, target kayu sebesar \pm 0.556 , dan target tanah sebesar $\pm 2.244 \mathrm{~mm}$. Hasil tersebut menunjukkan bahwa ketelitian selisih jarak antara pita ukur baja dan reflector-less kurang dari ketelitian alat yaitu $\leq \pm 3 \mathrm{~mm}$. Pengaruh jenis target didapat dari hasil analisis regresi dan korelasi berdasarkan selisih jarak antara pita ukur baja dan ETS reflector-less, penjelasan tentang hasil analisis tersebut disajikan pada Gambar 4. 


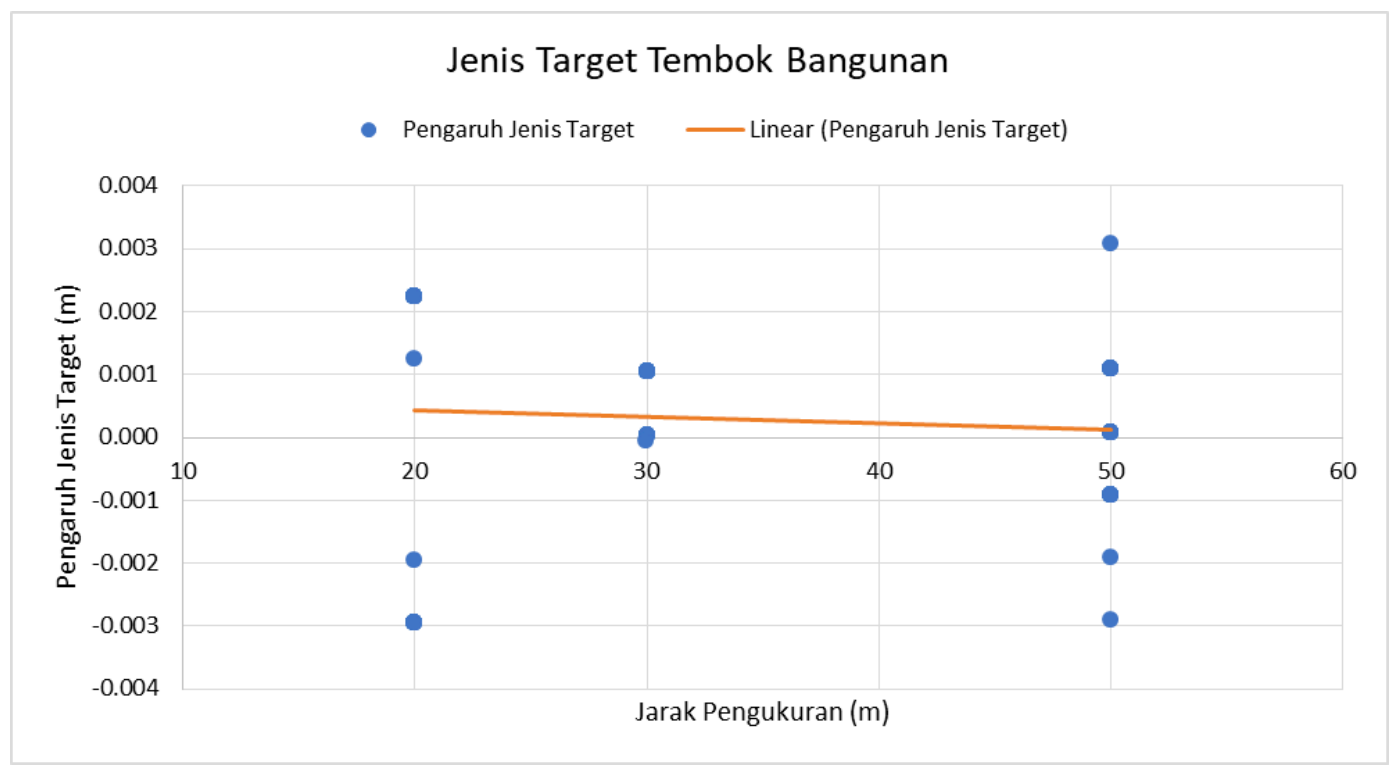

Gambar 4. Pengaruh Jenis Target Tembok Bangunan

Berdasarkan Gambar 4, hasil proses regresi dan korelasi menghasilkan nilai a sebesar 0.00014 , b sebesar 0.00001 , dan $r$ sebesar -0.079 . Berdasarkan nilai $r$ tersebut termasuk ke dalam korelasi linear negatif (berlawanan arah) atau terdapat hubungan negatif yang sangat lemah antara variabel $X$ dan $Y$. Nilai simpangan baku $Y$ (pengaruh jenis target) sebesar \pm $0.002 \mathrm{~m}$, maka dapat disimpulkan bahwa pengaruh jenis target tembok bangunan terhadap pengukuran jarak ETS reflector-less sebesar $\pm 0.002 \mathrm{~m}$ atau $\pm 2 \mathrm{~mm}$.

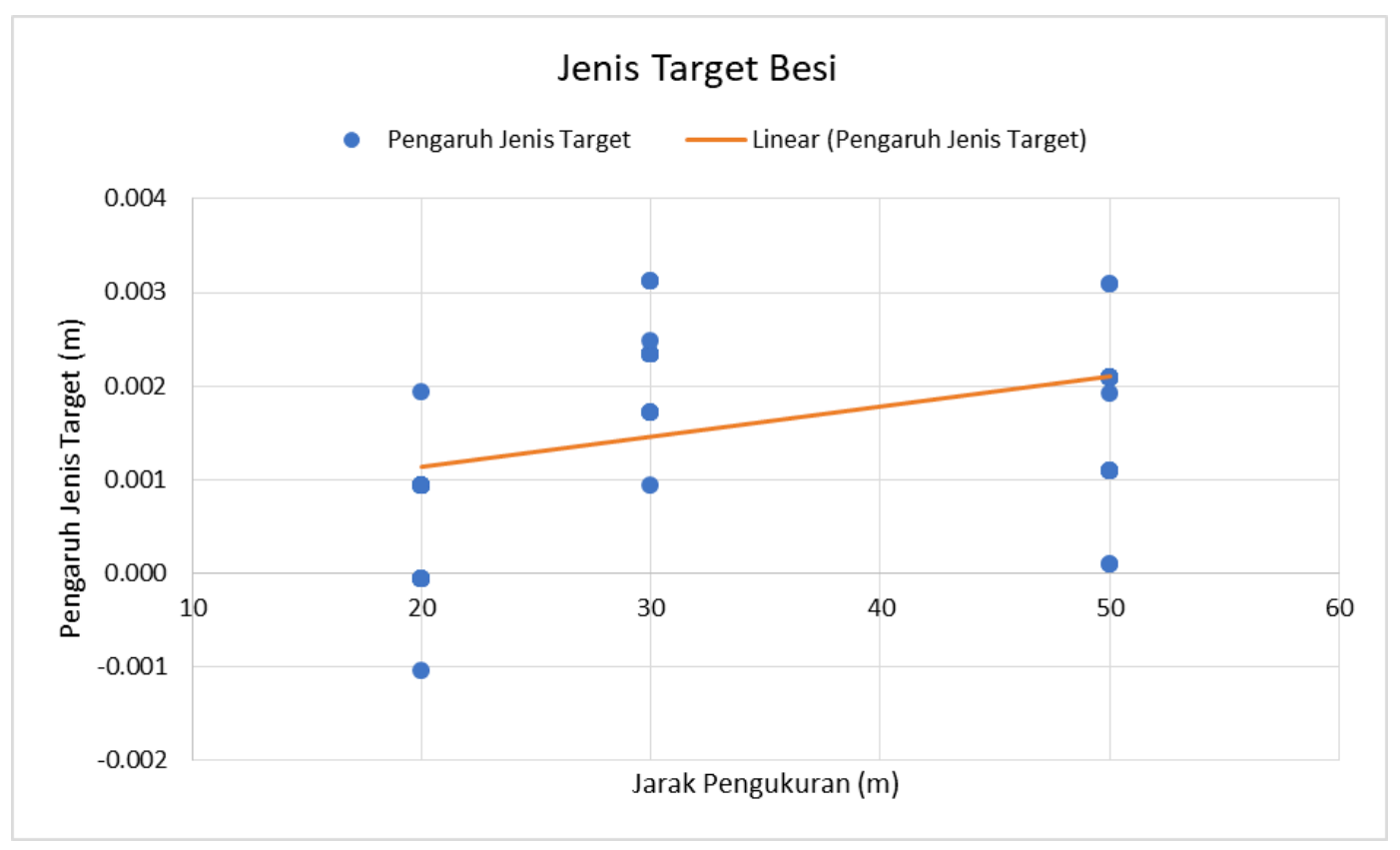

Gambar 5. Pengaruh Jenis Target Besi

Berdasarkan Gambar 5, hasil proses regresi dan korelasi menghasilkan nilai a sebesar 0.00048 , b sebesar 0.00003, dan $r$ sebesar 0.434 . Berdasarkan nilai $r$ tersebut termasuk kedalam korelasi linear positif (searah) atau terdapat hubungan positif yang lemah antara variabel $X$ dan $Y$. Nilai simpangan baku $Y$ (pengaruh jenis target) sebesar $\pm 0.002 \mathrm{~m}$, maka 
dapat disimpulkan bahwa pengaruh jenis target besi terhadap pengukuran jarak ETS reflector-less sebesar $\pm 0.002 \mathrm{~m}$ atau $\pm 2 \mathrm{~mm}$.

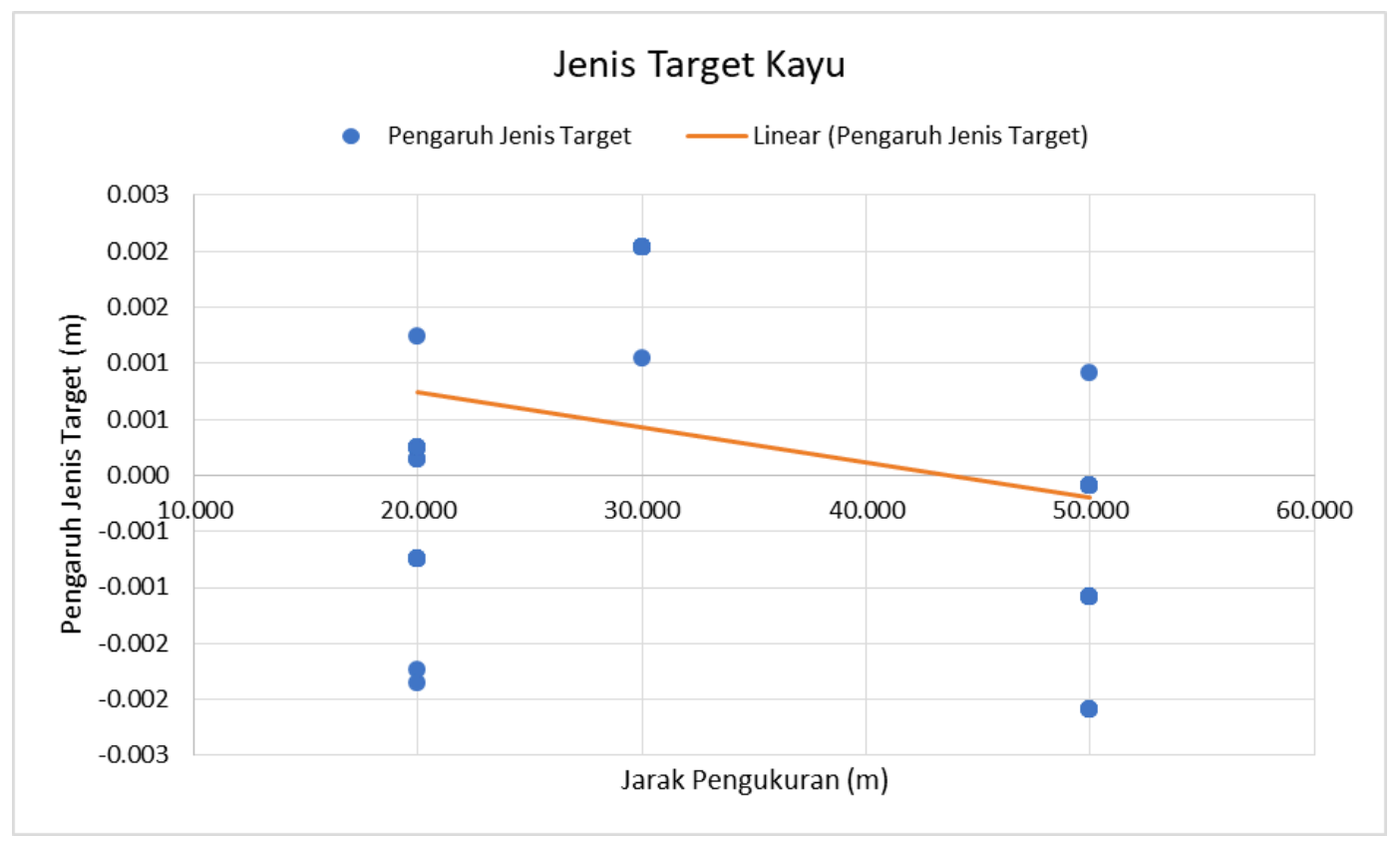

Gambar 6. Pengaruh Jenis Target Kayu

Berdasarkan Gambar 6, hasil proses regresi dan korelasi menghasilkan nilai a sebesar 0.00138 , b sebesar -0.00003 , dan $r$ sebesar -0.294 . Berdasarkan nilai $r$ tersebut termasuk kedalam korelasi linear negatif (berlawanan arah) atau terdapat hubungan negatif yang sangat lemah antara variabel $X$ dan $Y$. Nilai simpangan baku $Y$ (pengaruh jenis target) sebesar $\pm 0.001 \mathrm{~m}$, maka dapat disimpulkan bahwa pengaruh jenis target kayu terhadap pengukuran jarak reflector-less sebesar $\pm 0.001 \mathrm{~m}$.

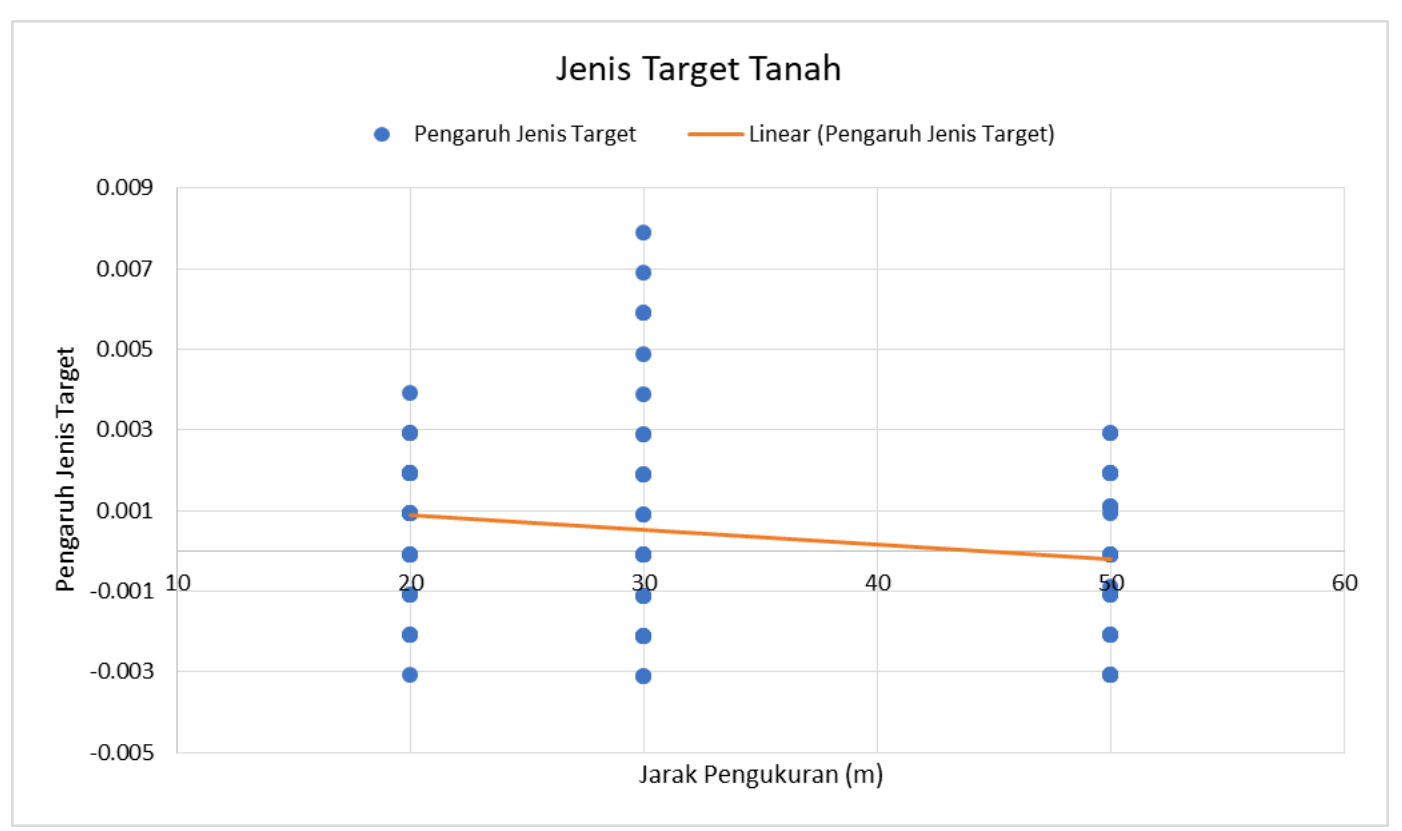

Gambar 7. Pengaruh Jenis Target Tanah 
Berdasarkan Gambar 7, hasil proses regresi dan korelasi menghasilkan nilai a sebesar 0.00162 , b sebesar -0.00004 , dan $r$ sebesar -0.193 . Berdasarkan nilai $r$ tersebut termasuk kedalam korelasi linear negatif (berlawanan arah) atau terdapat hubungan negatif yang sangat lemah antara variabel $X$ dan $Y$. Nilai simpangan baku $Y$ (pengaruh jenis target) sebesar $\pm 0.002 \mathrm{~m}$, maka dapat disimpulkan bahwa pengaruh jenis target kayu terhadap pengukuran jarak reflector-less sebesar $\pm 0.002 \mathrm{~m}$.

\section{KESIMPULAN}

Secara keseluruhan dari proses yang telah dilakukan pada penelitian ini dapat diambil beberapa kesimpulan berikut.

1. Rata-rata selisih jarak antara pita ukur baja dan ETS reflector-less untuk jenis target tembok bangunan sebesar $\pm 1.373 \mathrm{~mm}$ dan pengaruh jenis target tembok bangunan sebesar $\pm 2 \mathrm{~mm}$. Semakin panjang jarak pengukuran maka pengaruh jenis target tembok bangunan semakin kecil berdasarkan hasil regresi dan korelasi yaitu a sebesar 0.00014 , b sebesar 0.00001 , dan $r$ sebesar -0.079 .

2. Rata-rata selisih jarak antara pita ukur baja dan reflector-less untuk jenis target besi sebesar $\pm 0.576 \mathrm{~mm}$ dan pengaruh jenis target besi sebesar $\pm 2 \mathrm{~mm}$. Semakin panjang jarak pengukuran maka pengaruh jenis target besi semakin besar berdasarkan hasil regresi dan korelasi yaitu a sebesar 0.00048 , b sebesar 0.00003 , dan $r$ sebesar 0.434 .

3. Rata-rata selisih jarak antara pita ukur baja dan reflector-less untuk jenis target kayu sebesar $\pm 0.556 \mathrm{~mm}$ dan pengaruh jenis target kayu sebesar $\pm 1 \mathrm{~mm}$. Semakin panjang jarak pengukuran maka pengaruh jenis target kayu semakin kecil berdsarkan hasil regresi dan korelasi a sebesar 0.00138 , b sebesar -0.00003 , dan $r$ sebesar -0.294 .

4. Rata-rata selisih jarak antara pita ukur baja dan reflector-less untuk jenis target tanah sebesar $\pm 2.244 \mathrm{~mm}$ dan pengaruh jenis target tanah sebesar $\pm 2 \mathrm{~mm}$. Semakin panjang jarak pengukuran maka pengaruh jenis target tanah semakin kecil berdasarkan hasil regresi dan korelasi a sebesar 0.00162 , b sebesar -0.00004 , dan $r$ sebesar -0.193 .

\section{DAFTAR RUJUKAN}

Wolf, P. R. (1997). Adjustment Computations (Statistics and Least Square in Surveying and GIS). Canada: John Wiley \& Sons, Inc.

Ghilani, C. D. (2010). Adjustment Computations (Spatial Data Analysis), Edisi 5. Canada: John Wiley \& Sons, Inc.

Boediono, K. W. (2001). Statistika dan Probabilitas (Teori dan Aplikasi). Bandung: Remaja Rosdakarya, Offset.

Anonim. (1979). International Association of Geodesy. Dipetik Februari 27, 2017, dari http://www.iag-aig.org.

Anonim. (2017). Total Station Hi Target ZTS 320R. Dipetik Februari 23, 2017, dari http://www.hi-target.com.cn. 